\title{
Examination of Establishment of Psychological Contract of Foreign Manager in Hong Kong Foreign News Bureau with Local Employee \\ DOI: https://doi.org/10.47175/rissj.v2i1.174
}

\section{| Vincent Hing-Po Lam |}

\author{
Assistant Professor of Media \\ and Communication, Beijing \\ Normal University Hong Kong \\ Baptist University United \\ International College.
} vincentlam@uic.edu.cn

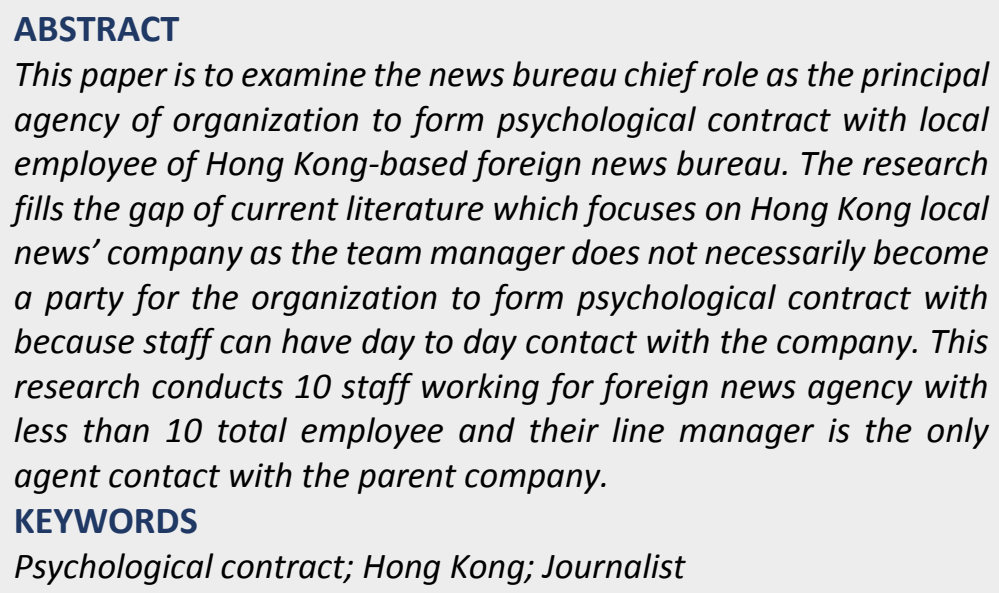
agency of organization to form psychological contract with local employee of Hong Kong-based foreign news bureau. The research fills the gap of current literature which focuses on Hong Kong local news' company as the team manager does not necessarily become a party for the organization to form psychological contract with because staff can have day to day contact with the company. This research conducts 10 staff working for foreign news agency with less than 10 total employee and their line manager is the only agent contact with the parent company.

KEYWORDS

Psychological contract; Hong Kong; Journalist

\section{INTRODUCTION}

A lot of foreign news bureau have had their presence in Hong Kong with a small term of less than 10 total employee. The manager in charge sent by the parent company in overseas has been the principal agency for local employee to form psychological contract with the parent organization. Due to this isolation, local employee is completely unaware of the working practice and human resource policy of parent company as the Bureau chief becomes the sole principal agency to define and interpret corporate values.

Employees had the impression that their managers are acting completely on behalf of the organization and their decision are fully endorsed by the organization (Levinson, 1962; Rousseau, 1995; Shanock \& Eisenberger, 2006). Therefore, employees would believe that when their bureau chief violated the psychological contract but not fully endorsing parent company's policy, the frustration will lead to the damage of psychological contract between a local employee with the parent company as their only contact with the parent company is through the bureau chief at local level. Therefore, contract breaches made by principalmanagers to their organization are one cause of the relatively high rate of employeeperceived contract breaches by the organization (e.g., Robinson \& Morrison, 2000; Robinson \& Rousseau, 1994; Turnley \& Feldman, 1998, 1999).

As such, the Bureau Chief role and power has been expanded to include human resources, finance, business development, and corporate value interpretation. The Bureau Chief has full power over hiring and firing, job performance review, and promotion decision because parent company has no idea of performance of local employee.

The concentrated power of Bureau Chief expands its position from an agent of organization to become the organization. The full power possessed by Bureau Chief creates a small kingdom in which even he/she acts completely in contrary of core values of parent 
organization, there is no human resources department involved from the parent company to mediate potential worsening of employer and employee relationship through bureau Chief.

\section{LITERATURE REVIEW}

Rousseau (1998) suggested that there are two types of psychological contract which are transactional (short term) and relationship (long term). The psychological contract originally is derived from the expectancy theory Oliver (1974)which proposes that an individual will behave or act in a certain way because they are motivated to select a specific behavior over others due to what they expect the result of that selected behavior will be.

However, at the core of the theory is the cognitive process of how an individual processes the different motivational elements. This is done before making the ultimate choice. The outcome is not the sole determining factor in making the decision of how to behave. The motivation of the behavior selection is determined by the desirability of the outcome.

The transanctional psychological contract is to pay attention on the explicit terms on the employment contract such as pay, working hour, holiday arrangement which is the general HR policy written as terms of the official employment contract.

Relational psychological contract, however, focuses on the interconnected factors which connect employer and employee with a high degree level of social exchange for a longer term of employment relationship. The relational contract focuses on the implicit agreement as a perceived exchange of agreement between an individual and another party that defines employer-employee relationships. The psychological contract is a type of social exchange relationship.

Table 1. Denise Rousseau is credited with outlining these 5 phases of contract formation:

\begin{tabular}{|l|l|}
\hline Pre-employment & $\begin{array}{l}\text { The initial expectations of the employee form through professional } \\
\text { norms and societal beliefs that may be influenced by information } \\
\text { gathered about the organization and how certain occupations are } \\
\text { portrayed by the media. }\end{array}$ \\
\hline Recruitment & $\begin{array}{l}\text { The first instance of two-way communication involving promise } \\
\text { exchanges between employer and prospective employee during the } \\
\text { recruiting process. }\end{array}$ \\
\hline $\begin{array}{l}\text { Early } \\
\text { socialization }\end{array}$ & $\begin{array}{l}\text { Promise exchanges continue with both parties actively continuing } \\
\text { their search for information about one another through multiple } \\
\text { sources. - }\end{array}$ \\
\hline Later experiences & $\begin{array}{l}\text { The promise exchange and search for information processes slow } \\
\text { down as the employee is no longer considered new. There may be } \\
\text { changes to the psychological contract introduced at this stage. }\end{array}$ \\
\hline Evaluation & $\begin{array}{l}\text { The existing psychological contract is evaluated and possibly } \\
\text { revised and it is determined whether revision is needed. Incentives } \\
\text { and costs of change impact revision }\end{array}$ \\
\hline
\end{tabular}

In essence, this theory emphasizes the needs for organizations to relate rewards directly to performance and to ensure that the rewards provided are those rewards deserved and wanted by the recipients Montana (2008).

This consensus identifies psychological contracts as "promissory, implicit, reciprocal, perceptual, and based on expectations George (2016)

The psychological contract therefore shads light on how the unspoken rule of implicit contract of a company have an impact on the establishment of a smooth employment 
relationship with an employee. In most cases, the employee at ground work level is too distant from the central management and it is often the line manager responsible for the daily supervision of an employee who implements the company's policy is whom an employee forms a psychological contract with.

\section{RESEARCH METHODS}

On this research setting, the foreign manager sent by their home parent company in HK News office is the agent through which the local employee forms the physiological contract. The agent (Bureau Chief) carries out that works of a principal (parent company) which delegates a decision making authority to agent to perform a service on their behalf in dayto-day management of the overseas office.

This paper will look at if the role of bureau chief for the formation of psychological contract for the parent company as a communication agent between locally-hired staff and the parent management from the perspective of relational (implicit) for long term employment and transactional (explicit) short term employment.

Whether the psychological contract of HK local employee is formed to the agent (which represents the parent company) or the parent company (which a local employee rarely knows any one in there or know how things work there).

In addition, whether the agent himself has set a different sets of management rules which go in conflict with the general human resource policy of the parent company in the home office. Therefore, an agent may not act in the best way for the best interests of the principal because they consider the loyalty of local staff is formed with the Bureau Chief instead of the parent company in home country.

As such, this search focuses on evaluating implicit (formed with bureau chief himself or the parent company) or the explicit contract as a standard term of employment contract universal to every employee.

10 locally-hired Hong Kong local employees working for US and UK news bureau with less than 10 total employees in Hong Kong office. The research will be conducted by survey and open discussion interview.

The research result will be analyzed of what local employee would expect the parent company do in terms to enhance and consolidate the psychological contract in both implicit and explicit terms. In addition, how the bureau chief as an agent in position to act as connecting platform for the successful construction of psychological of both parties. Or simply, the psychological contract is only formed between the bureau chief and local employee but never the parent company.

\section{Hypothesis}

This paper has three Questions;

1; In what degree Hong Kong local employee considers themselves to work for the parent organization or the bureau chief?

2; How much do you agree your Bureau Chief fully play the role as an agent to form psychological contract with parent organization

3; What can principal agent (bureau Chief) do for local employee to enhance the formation of psychological contact with the parent organization? 


\section{Research Report}

\section{Survey for Question one}

1. In what degree Hong Kong local employee considers themselves to work for the parent organization or the bureau chief?

\begin{tabular}{|c|c|c|}
\hline & Bureau Chief & Parent company \\
\hline 1 & & $\mathrm{X}$ \\
\hline 2 & & $\mathrm{X}$ \\
\hline 3 & & $\mathrm{x}$ \\
\hline 4 & & $\mathrm{x}$ \\
\hline 5 & & $\mathrm{x}$ \\
\hline 6 & & $\mathrm{x}$ \\
\hline 7 & & $\mathrm{x}$ \\
\hline 8 & & $\mathrm{x}$ \\
\hline 9 & $\mathrm{x}$ & \\
\hline 10 & $\mathrm{X}$ & \\
\hline
\end{tabular}

\section{Survey for the Question Two}

2. How much do you agree your Bureau Chief fully play the role as an agent to form psychological contract with parent organization

\begin{tabular}{|l|l|l|l|l|l|}
\hline & $\begin{array}{l}\text { Fully } \\
\text { Exercise } \\
(5)\end{array}$ & $\begin{array}{l}\text { Almost } \\
\text { Experience } \\
(4)\end{array}$ & $\begin{array}{l}\text { Partly } \\
\text { Exercise } \\
(3)\end{array}$ & $\begin{array}{l}\text { Little } \\
\text { Exercise } \\
(2)\end{array}$ & $\begin{array}{l}\text { No } \\
\text { Exercise } \\
(1)\end{array}$ \\
\hline 1 & $\mathrm{x}$ & & & & \\
\hline 2 & & $\mathrm{x}$ & & & \\
\hline 3 & $\mathrm{x}$ & & & & \\
\hline 4 & $\mathrm{x}$ & & & & \\
\hline 5 & & $\mathrm{x}$ & & & \\
\hline 6 & $\mathrm{x}$ & & & & \\
\hline 7 & $\mathrm{x}$ & & & & \\
\hline 8 & & $\mathrm{x}$ & & & \\
\hline 9 & $\mathrm{x}$ & & & & \\
\hline 10 & $\mathrm{x}$ & & & & \\
\hline
\end{tabular}

\section{Interview question for Question 3}

3. What are the suggestions for local employee to enhance the formation of psychological contact with the parent organization?

\begin{tabular}{|c|l|}
\hline 1 & $\begin{array}{l}\text { Hong Kong office to entitle with the same benefit package on the promotion } \\
\text { and annual leave with parent company }\end{array}$ \\
\hline 2 & Rotating work office and experience the work culture in parent company \\
\hline 3 & I don't care as long as I am paid \\
\hline 4 & $\begin{array}{l}\text { I enjoy flat hierarchy system and there is no need for me to handle HR, } \\
\text { Finance and other company department instead of my boss alone }\end{array}$ \\
\hline 5 & My boss is only an administrative post as the team head is in London \\
\hline 6 & $\begin{array}{l}\text { I prefer the job evaluation is to be reviewed independently by HR } \\
\text { department because my boss may have his independent preference on } \\
\text { promotion }\end{array}$ \\
\hline 7 & \begin{tabular}{l} 
I feel no sense of belonging to the parent company because I report to my \\
\hline
\end{tabular} \\
\hline
\end{tabular}




\begin{tabular}{|c|l|}
\hline & $\begin{array}{l}\text { bureau chief only and he is the only who knows what I am doing and he can } \\
\text { fire me. }\end{array}$ \\
\hline 8 & $\begin{array}{l}\text { Job training should be carried out in the parent company office so that I get } \\
\text { to know the working of the company after I start to work in Hong Kong } \\
\text { branch office }\end{array}$ \\
\hline 9 & $\begin{array}{l}\text { There are lots of equal opportunity mechanism in the parent company such } \\
\text { as maternity leave, study allowance, medical plan, and longer holiday. } \\
\text { However, only my boss and colleagues hired by parent company is entitled } \\
\text { for those benefits }\end{array}$ \\
\hline 10 & $\begin{array}{l}\text { There are only three staff in my office. I can hardly tell if I am working for } \\
\text { the company or for my boss only because the values of parent company is } \\
\text { interpreted by him. }\end{array}$ \\
\hline
\end{tabular}

\section{RESULTS AND DISCUSSION}

The comment is summarized into the formation of implicit and explicit contract of the psychological contract from the role of Bureau chief on the question no 3.

\begin{tabular}{|l|l|l|}
\hline & Implicit Contract & Explicit Contract \\
\hline Comment & 2 & 1 \\
\cline { 2 - 3 } & 4 & 3 \\
\cline { 2 - 3 } & 7 & 5 \\
\cline { 2 - 3 } & \multirow{3}{*}{10} & 6 \\
\cline { 2 - 3 } & & 8 \\
\cline { 2 - 3 } & & 9 \\
\hline
\end{tabular}

\begin{tabular}{|l|l|}
\hline Pre-employment & \\
\hline Recruitment & 5,8 \\
\hline $\begin{array}{l}\text { Early } \\
\text { socialization }\end{array}$ & $1,2,3,4,7,9,10$ \\
\hline Later experiences & 6 \\
\hline Evaluation & 6 \\
\hline
\end{tabular}

The research shows that the despite Hong Kong employee has not had any experience working for parent company, their psychological contract with the parent company still exists. Their psychological contract connected with the parent company is still established via their bureau chief who is the agent of the parent company.

Taken a closer look at their comment of the experience in the workplace, the majority of them started to form psychological contract at the later experience during employment instead of at the entry stage of early socialization or during the job evaluation process as they have the most extensive interaction with their boss (bureau chief) who basically supervises their work, train their job skill, decide extension of their employment contract, and deliver the company values on behalf of the parent company.

However, the research still shows that $60 \%$ of the respondents considers explicit contract as standard term for employment contract to be very important to form the psychological contract with the parent company as summarized as (1, same benefit package; 3 Pay package; 5 seeing the boss in HK only as administrative post not the employee's real boss, 6 central HR in home office to carry out the job evaluation; 8 Job training carried by the parent office; 9 equal opportunity mechanism).

The summary of expectation of same explicit term on the employment contract is to ensure that they dont feel as being treated as a second class employee under one company. 
$40 \%$ of the interviewees of the considers implicit contract as important to form the psychological contract via the agent either through bureau chief or directly with the parent company) as summarized as (2, rotate work in the home office; 4 enjoying dealing with the boss alone rather than the complicated unfamiliar company culture; 7 loyalty to only bureau chief as this position has the power to fire him; 10 only know the culture of parent via bureau chief).

The research also shows that the psychological contract through the application of Rousseau (1998) in this content mostly occur in the stage of later experience. Only two interviewees were so eager to integrate into the culture of parent company whom they consider the psychological contract was formed to instead with the bureau chief.

It is also discovered that most staff prefer more detailed explicit contract because it is more transparent as clearly written as terms of contract prior to the entering into official employment relationship.

The censuses is that more unspoken roles leave bigger room for agent to manoeuvre or not to follow the parent's company general employment policy. That uncertainty on how the employment relationship works may result in the staff to start evaluating the fulfillment on the successfully formation of psychological contract in rather late stage of employment because it takes time to grope around the culture and personal working style of their immediate boss as an agent of the parent company.

As such, it may take much longer than to what is expected in the company and what specific behavior is motivated to form implicit contract of psychological contract. As the research shows that $80 \%$ of the interviewees consider themselves to form psychological contract with the parent company not the Bureau Chief. Therefore, prior to the employment, they are drawn to the values and image and pay of the company as the principal instead of the agent.

\section{CONCLUSION}

The research shows that the local Hong Kong staff's initial bond of the psychological contract is with the parent company prior before entering to the company. Once entering into the employment relationship, only 2 out of 10 considers their psychological contract formed with the parent company is via the bureau chief which is only the agent of parent company.

They share the same values with parent company only. However, due to the remote connection with the parent company and the isolation of the home office in the parent company, the words and implementation of HR policy from the Bureau Chief becomes the only source of connection between overseas staff and parent company.

Therefore, seven out of 10 staff interviewed considered the bureau chief fully play the role as an agent to form psychological contract with parent organization. 3 out of 7 also rated most experience so that the role of Bureau Chief without the further interview of Human Resource department from the parent company is therefore prominent on the successful formation of psychological contract.

The comments from their view opens more room to understand the situation in more holistic way of how the psychological contract is formed through implicit contract or explicit contract

However, the agency theory is also established because the agent (bureau Chief) is the one which interprets the values of parent company and exercise the parent company's full administration power over staff.

A majority staff believes that a stronger bonding can be established if they could have direct contact and working experience with same employment package with staff of the parent organization. 
In addition, more explicit term on the employment contract to standardize what behaviors are expected help staff to fit into the company's culture at the earlier stage of employment. As implicit contract takes much longer time to form and there is a great variation between different preferences of individual supervisor over the implementation of psychological contract as staff's primary contact with the parent company in home country is through the Bureau chief which may not live up or closely follow the expectations of staff culture if there have not had any clear written terms for all parties (Parent company, bureau chief, local staff) to follow.

\section{REFERENCES}

George, Chris teen. Psychological Contract: Managing and Developing Professional Groups. Maidenhead, GB: Open University Press, 2010. Chapter 1: Introducing the psychological contract. Web. 14 October 2016.

Levinson, H. (1962). Organizational diagnosis. Cambridge. MA: Harvard University Press Montana, Patrick J; Charnov, Bruce H. (2008). Management. Barron's Educational Series, Inc

Oliver, R. (1974). Expectancy Theory Predictions of Salesmen's Performance. Journal of Marketing Research 11(3), 243-253.

Robinson, S. L., \& Morrison, E. W. (2000). The development of psychological contract breach violation: A longitudinal study. Journal of Organizational Behavior, 21, 525546. Robinson, S. L., \&

Robinson, S. L., \& Rousseau, D. M. (1994). Violating the psychological contract: Not the exception but the norm. Journal of Organizational Behavior, 15, 245-259.

Rousseau, D. M. (1995). Psychological contracts in organizations: Understanding written and unwritten agreements. Thousand Oaks, CA: Sage

Rousseau, Denise M. (1998). "The 'Problem' of the Psychological Contract Considered". Journal of Organizational Behavior. 19: 665-671

Shanock, L. R., \& Eisenberger, R. (2006). When supervisors feel supported: Relationships with subordinates' perceived supervisor support, perceived organizational support, and performance. Journal of Applied Psychology, 91, 689-695.

Turnley, W. H., \& Feldman, D. C. (1998). Psychological contract violations during corporate restructuring. Human Resource Management, 37, 71-83.

Turnley, W. H., \& Feldman, D. C. (1999). The impact of psychological contract violations on exit, voice, loyalty, and neglect. Human Relations, 52, 895-922. 